\title{
Academic Procrastination in terms of Student Self-Concept and Self- Efficacy
}

\author{
Ulfiani Rahman ${ }^{1}$, Idham ${ }^{2}$ \\ ${ }^{1}$ Universitas Islam Negeri Alauddin Makassar, Indonesia \\ ${ }^{2}$ Religious Research and Development Agency, The Ministry of Religious Affairs, Indonesia \\ 11ulfiani.rahman@uin-alauddin.ac.id, 2idhambodi73@gmail.com
}

\begin{abstract}
Among the causes of the student academic procrastination in religion-based universities are the low self-concept and self-efficacy. Hence, this research of this study to determine the effects of self-concept and self-efficacy on student academic procrastination of the faculty of Education and Teaching. The method used in this research is the quantitative approach. Subjects in this study were students of faculty of education and teaching Subjects amounted to 189 students from a population of 1,892 students who were obtained through proportional random sampling techniques. Research instrument in the form of Self-Concept Scale, Self-Efficacy Scale, and Academic Procrastination Scale. Data were analyzed using inferential statistical analysis by multiple linear regression techniques. The inferential analysis showed for the hypothesis testing results that there is significant influence self-concept and self-efficacy together toward academic procrastination. The effective contribution of self-concept and self-efficacy to academic procrastination by $30,1 \%$. This means that procrastination is also influenced by many other factors, such as conformity, closed and open personality.
\end{abstract}

Keywords

Self-Concept, Self-Efficacy, Student Academic Procrastination

Article Received: 10 August 2020, Revised: 25 October 2020, Accepted: 18 November 2020

\section{Introduction}

Based on the survey, it shows that many students do academic delays during college and this is a common practice. Research on academic procrastination is mostly done at public universities but has not been found in many faithbased universities. The causes of the procrastination based on information on 75 fourth semester students majoring in mathematics education, were $33 \%$ of students lacking understanding of college assignments, $1 \%$ who thought the assignments were less attractive, $7 \%$ were less motivated to learn, $15 \%$ delayed assignments because there were other activities, and $44 \%$ of students spend time completing assignments. (Observation, March 18, 2018). This shows the low self-concept and self-efficacy of students. The big difference in the motivation of each student in completing college assignments is because they spend time relaxing or more placing other work more urgently outside the lecture, lacking confidence in their abilities, but realize that if not immediately resolved can cause psychological problems such as anxiety because there are sanctions that will be borne for example reprimands, socially shunned, showing low selfconcept with delays because work shows social attitudes again, low confidence in his abilities (low self-efficacy) (Interview, March 18-2018). To describe a tendency of delaying completion of a task or job that someone failed to complete the tasks on time person who tends to postpone when facing a task called do procrastination. Performer's delay or procrastination is called procrastination.

Furthermore, the results of research conducted by Hussaina and Sultan (2010), concluded that procrastination effects the academic performance of students in terms of classroom learning and participation in activities, submission of their assignments, preparing for the examinations, and achievement. Handayani (2012), Rahmawati (2011) which shows a negative correlation between self-concept and academic procrastination. This means that the higher the self-concept of a student, the more academic procrastination tends to decrease. While the results of research on the 
relationship between self-efficacy and procrastination also show that there is a negative relationship between self-efficacy and procrastination. This means that the higher the selfefficacy of a student the lower the task of procrastinating academic behavior (Momani, 2018). The research conducted together on the two variables showed the influence of self-concept and self-efficacy on the guidance of academic procrastination was still limited.

The big difference in the motivation of each student in completing college assignments is because they spend time relaxing or more placing other work more urgently outside the lecture, lacking confidence in their abilities, but realize that if not immediately resolved can cause psychological problems such as anxiety because there are sanctions that will be borne for example reprimands, socially shunned, showing low selfconcept with delays because work shows social attitudes again, low confidence in his abilities (low self-efficacy) (Interview, March 18-2018).

Procrastination term first used by Brown and Holtzman (1953) to describe a tendency of delaying completion of a task or job that someone failed to complete the tasks on time person who tends to postpone when facing a task called do procrastination. Performers delay or procrastination called procrastinator.

Procrastination is delaying deliberately the desired activity even though people know that the behavior of the delay can result in adverse effects. Delay is said to procrastinate if the delay is committed intentionally and will be bad for the culprit. Solomon and Rothblum (1984) suggest that procrastination is the delayed initiation or completion of tasks do intentionally. From these definitions, it can be seen that procrastination is intentional behavior because the factors that delayed the completion of the task is his own decision. There is also a common type of procrastination that can be divided into several terms: Procrastination negative and positive, Procrastination passive and active (Chu \& Choi, 2005; 250), Procrastination Functional and dysfunctional.
Aspects of Academic Procrastination according to Ferrari et al (1995: 161) argues that as a behavioral delay, academic procrastination can be manifested in certain indicators that can be measured and observed in certain aspects, as follows: 1. Delays to start and complete the task. It is intended that the task facing individuals must be resolved and useful itself, but the people procrastinate to do it or finish it once and for all if already started working on before. 2. Delay in doing the task. Individuals who do procrastination takes longer than the time required is generally in a task. 3. Make the activity more enjoyable. Procrastinators were not immediately complete the task because they are more favored to prioritize tasks and bring entertainment such as reading newspapers, books, watch, talk, listen to music, and so on, so it took a lot of time. 4 . The difference between the planned and actual performance. A procrastinator has difficulty in doing work that had been planned advance. Typically, procrastinators experiencing delays in the work plan of his duties, which are planned by others and had planned its own. As a result, the work should be completed delay.

The fourth aspect of the procrastination shown that individuals do procrastination includes delays completing the task, the delay in doing the task, the time gap between planned and actual performance as well as doing other activities are more fun than on what should be done.

The theory may underlie procrastination include the theory of behaviorism of Skinner. Skinner introduced the theory of operant conditioning with reward terms and punishment. This theory states that procrastination behavior arises because of the learning process. An ever tasted success in performing a task, then it will usually tend to repeat the job or task at the next opportunity. This can be considered as a gift (reward). The existence of other activities are more enjoyable than procrastination activities it will bring academic procrastination behavior. For example, to play the game will be more fun than doing schoolwork.

While a job was well done does not have a significant effect, tends to be avoided and it is customary in analogy with punishment (punishment). Examples relating to academic 
procrastination among others is a student who had to delay completing tasks that must be collected before the semester exam, it tends to be delayed compared to the task to be prepared every week. This occurs because the value of the punishment of both tasks tends to be stronger obtained on completion of weekly assignments that have to postpone the semester assignment punishment level lower than the weekly task.

Besides, it can also rely on cognitive theory. Procrastination occurs because the belief is unreasonably experienced by someone on the tasks to be completed. This occurs because the task is considered heavy and difficult to resolve, and the fear of failure (Kandemira, Mehmet, 2014). As a result, he was put off to finish the job then, the term self-efficacy introduced by Albert Bandura. According to social cognitive theory, man is not only driven by the force from within himself, and not also established itself automatically and controlled by outside stimuli. More precisely, the human function is described in a reciprocal relationship between behavioral and cognitive factors (personal) and the environment (Bandura 1986). Self-efficacy is believed to be the determinant of the success of the work. Besides, self-efficacy may also affect patterns of thought and behavior in making a decision. In short, selfefficacy by Bandura (1994) is the level of confidence in the ability of individuals themselves to perform a specific task. This relates to the situation at hand and placed the individual as part of the cognitive processes in learning. Also state that self-efficacy is the ability of individuals to perform certain tasks. It's not much different from Burns (1993) which states that self-efficacy is a concept of the self associated with the ability and expertise in performing a particular task. Therefore, self-efficacy is feeling confident in the ability itself in making an action.

It shows that people can feel the freedom in doing activities he likes and responsible for his actions, has the warmth and decency in establishing communication with other individuals. Besides, individuals may accept and respect other people, have the drive to succeed, and can understand the advantages and disadvantages, so it can fix the problem.
Some of the above definitions indicate where the subjective nature of self-efficacy, self-efficacy that does not always show the ability that is fitting but relates to confidence in the ability of the individual to do the job and overcome a variety of problems. Thus, self-efficacy in the context of learning undertaken by students interpreted as a judgment of conviction subjectively on the business or its ability to design, organize and carry out the activities required to achieve the educational goals set (Bandura 1977).

The belief that every individual can control the mind, feelings, and behaviors, based on social cognitive theory. Self-efficacy is not something innate or genetic, but acquired, learned, and developed from several sources (Bandura, 1986, 1994) among them; Enactive mastery experiences and achievement; The experience of other individuals; Verbal Persuasion; physiological and emotional state.

In addition to the efficacy of the above, another important thing in self-efficacy is the processes that drive efficacy. In this case, there are four physiological processes primarily through belief in the ability of self that affect human functioning (Bandura 1994), among them: Cognitive processes (the main function of thinking of them, allowing individuals predict an event and develop a way of escort that can affect life); The process of motivation (self-efficacy plays an important role in regulating self-motivation, where people motivate himself, guide his actions, and oversee the exercise); The process of affective (emotional) (Confidence ability to influence how people will cope with the stress and pressures experienced in difficult situations). So far the election process, the ability of the self-activation process allows individuals to create environments favorable and train yourself how to guard them.

Then to activating the process of self-efficacy above, there are also components of self-efficacy. He may be a basis in determining how to measure the efficacy. However, Bandura does not specifically provide a measuring tool that respects but only convey basic concepts related to constructs made. Bandura $(1977,2005)$ stated that 
self-efficacy components area. The level of difficulty of the task (magnitude), that is, individuals would choose a job based on the ability to perform a task. $b$.

The power of faith (strength), that is related to the strength of conviction of individuals about their ability; c. Generalization (generality), that is associated with one activity and specific situations or in areas of work are many and varied situations. Based on the above, it can be concluded that selfefficacy is composed of three dimensions namely the level (degree of difficulty), generality (breadth), and strength (resistance).

While Hurlock (2000: 238) argues that selfconcept plays a role in the behavior of individuals because the whole attitude and outlook of the individual against his will affect the individual in interpreting every aspect of his experience. The interpretation of the individual against the event something much influenced by the attitudes of the individual to himself. It also determines the willing individual. Hope is the core of the concept of self, it is the goal, the ideal individual who always wanted to accomplish to achieve inner balance fun.

Aspects of self-concept in this research is to use the theory of Burns (1993) on self-concept, covering aspects: 1). Physical self -image, composed of the body such as high quality or short, thin or fat, there is a defect or not; 2). Psychological self-image, consisting of a wide range of traits, such as shy, honest, simple, miserly or aggressive; 3). Real self-image, is a reflection of the core that is what others are meant to him as parents, teacher, good friends, the physical and psychological terms; 4). Ideal self-image, the desired image by teenagers both physically and psychologically. It is a standard specified by him their hopes and aspirations are based on knowledge or assumption of their social environment. Therefore, this study aims to examine the effect of self-concept and self-efficacy on academic procrastination.

\section{Methods}

This study used a quantitative approach with a causality design to examine the effect of self- concept and self-efficacy on academic procrastination. The population in this study were students of the Tarbiyah and Teaching Faculty of UIN Alauddin Makassar in the totaling 1,892 students with a sample size of $10 \%$ of the total population so that 189 students were determined by proportional random sampling technique (Artikunto, 2010: 131). The determination of the sample is based on the criteria that students have knowledge and learning experience in higher education and things that need to be done so that all courses can be completed on time.

Data collection techniques were carried out using 3 scales, namely: 1. Procrastination scale consisting of 20 items relating to four domains, including a. Delays in starting and completing tasks; $b$. postponement of duties; c. make the activity more enjoyable; d. difference between plan and actual performance; The reliability value of the Procrastination Scale was 0.888; 2. Self-concept scale, consisting of 19 items.

There are four aspects of self-concept, namely: a. Physical self-image. b. Psychological self-image; c. Real self-image; 4. Ideal self-image; The reliability value of the self-concept scale was $0.611 ; 3$. The Self Efficacy scale consists of 29 statement items relating to three aspects including a. Level (Task Difficulty); b. Strength (stability or trustworthiness); c. Generality (Wide Field Behavior). The reliability value of the self-efficacy scale was 0.815 .

Furthermore, before testing the hypothesis, a prerequisite test is carried out using the data normality test, linearity test, and multi-linearity test. Then the hypothesis is tested using inferential analysis with multiple regression analysis techniques.

\section{Result and Discussion}

\section{Result}

\section{Assumption Testing}

Before conducting multiple regression analyses to answer the research hypothesis, first, the assumption test is carried out, namely the data 
normality test and the multicollinearity test, as stated in Table 1 and Table 2.

Table 1. Test of Normality

\begin{tabular}{lll}
\hline Variabel & Nilai KS- \\
& $\mathrm{Z}$ & Keterangan \\
\hline
\end{tabular}

Self-Concept

Self - Efficacy $\quad 0,688$

$0,731 \quad \mathrm{p}>0,05$

Procrastination

(normal)

Table 2. Test of Multicolinierity

\begin{tabular}{|c|c|c|c|}
\hline Variabel & $\begin{array}{l}\text { Nilai } \\
\text { VIP }\end{array}$ & $\begin{array}{l}\text { Nilai } \\
\text { Tolerance }\end{array}$ & Keterangan \\
\hline Self -Concep & & 1.092 & 0.916 \\
\hline \multicolumn{3}{|c|}{$p>0.05$} & 0.916 \\
\hline
\end{tabular}

Table 1 shows the value of KS-Z which is normally distributed because the $\mathrm{P}$ value is 0.731 > 0.05 . While in table 2 above shows a value that is free from multicollinierity because the VIF value is less than 10 and the tolerance is more than 0.1 , namely $0.916>0.05$.

\section{Hypothesis testing}

Based on the results of multiple regression analysis found that there are significant jointly self-concept

Table 4. Model Summary

\begin{tabular}{|c|c|c|c|}
\hline R Square & $\begin{array}{l}\text { Adjusted } \\
\text { R Square }\end{array}$ & $\begin{array}{l}\text { Std. Error of } \\
\text { the Estimate }\end{array}$ & F ChageSig.F.Change \\
\hline .309 & .301 & 6.52167 & 41.501 \\
\hline
\end{tabular}

Table 4 shows the determination analysis used to determine the percentage contribution of the influence of the independent variables together with the dependent variable. Based on the analysis of figures obtained Adjusted R Square of 0.301 $(30,1 \%)$. This means that the percentage and self efficacy against academic procrastination. But before put forward the results of multiple regression analysis, regression analysis can also partially exposed.

Table 3. Coefficients regression

\begin{tabular}{|c|c|c|c|}
\hline \multirow[t]{2}{*}{ Model } & $\begin{array}{l}\text { Unstandardized } \\
\text { Coefficients }\end{array}$ & \multicolumn{2}{|c|}{$\begin{array}{l}\text { Standardized } \\
\text { Coefficients }\end{array}$} \\
\hline & B $\quad$ Std Error & $\begin{array}{l}\mathrm{t} \\
\text { Beta }\end{array}$ & Sig \\
\hline (Constant) & 82.308 & 13.708 & .000 \\
\hline Self Efficacy & $\begin{array}{l}y-.688 \quad .077-.567\end{array}$ & -.8 .900 & .000 \\
\hline Self Concept & t.116.160 .046 & .722 & .471 \\
\hline
\end{tabular}

Based on the results of the partial regression coefficient analysis, it can be shown in Table 3 by testing the two sides (significance 0.025 results obtained for the $t$ table of 0.674 . So it can be compared $t$ calculate $>t$ table $(0.722>0.674) \mathrm{H} 0$ is rejected. This means that the analysis is part of the variable self-concept that shows their influence on academic procrastination. Value t count is positive, meaning that the effect is happening is positive, so the higher self-concept increases student academic procrastination.

Furthermore, by testing the two sides (significance -0.025 for the results obtained t table of 0.674 , so it can be compared $t<t$ table $(-8.900<-0.674)$ then $\mathrm{H} 0$ is rejected. This means that the partial analysis of the variables of self-efficacy showed their influence on academic procrastination. The $t$ value is negative, meaning that the effect is happening is negative, so the better the efficacy of self-declining student academic procrastination. 
The results of the regression equation significance test can see Fcalculate statistics price of 41.501, and $F$ table value of 3.04 the value of $F$ table is equal to so that $\mathrm{F}$ count $>\mathrm{F}$ table. This shows that self-concept and self-efficacy affect academic procrastination.

\section{Discussion}

Results of statistical analysis using multiple regression analysis showed that there are significant effects self-concept and self-efficacy on academic procrastination. The results showed that self-concept and self-efficacy significantly affect students' academic procrastination Tarbiyah and Teaching Faculty. Thus the hypothesis is accepted. This means that increasing self-concept and self-efficacy will decrease anyway student academic procrastination.

Research on procrastination was conducted on students who are in academic environments, thus in this study uses the term academic procrastination. Ferrari, et.al (1995) defines academic procrastination as a kind of delay do to this type of formal duties related to the academic field. Academic procrastination refers to delay work on assignments in the academic field it is not possible to achieve optimum performance. Thus, it can be concluded that procrastination is a person's tendency to procrastinate doing or completing the task he was facing a deliberate and repeated that will result in the individual can not complete tasks on time and the maximum or even fail to finish. While academic procrastination is delay done on assignments in academic. Procrastination can be done in some kind of work. Green (1982) stated that type of task that becomes the object of the study of academic procrastination is a task related to academic performance.

Solomon \&Rothblum (dalamMera M, K., Sunny, H,L., Kevin,J, 2001) divides, the six academic areas where common procrastination. Six academic areas, namely: 1). The task of composing, including delays obligations or writing tasks, such as writing papers, reports, or other fabricated tasks; 2). The learning exam includes a delay for the exam, for example, the midterm, the end of the semester, or repeat weekly; 3). Reading assignments include the delay to read the references relating to the academic work required. 4). Administrative tasks, such as copying records, a list of participants practicum, and so forth; 5). Attending the meeting, namely the delay or delays in attending practical lessons, and other gatherings; 6). Academic performance, delays in overall academic performance, that is, delay doing or completing academic tasks as a whole. It can be concluded that the area of academic procrastination is the task of composing, studying for exams, reading tasks, administrative tasks, attend meetings and academic performance. procrastination of other academic procrastinations were discovered when developing a thesis as results of the research Six patterns emerge from the data 1) Traveling, 2) Only lying on the bed and watching TV in boarding house, 3) Talking about something unimportant, 4) Going home, 5) Doing physical activities, and 6) Having jobs like coach and referee. These procrastination behaviors form specific patterns based on student's experience and background (Soegiyanto, et.al., 2017. Behavior Patterns Of Academic Procrastination In Doing Final Projects. Cakrawala Pendidikan, Oktober 2017, Th. Xxxvi, No. 3

Factors that Influence the Academic Procrastination can be categorized into two kinds (Ghufron, 2012), namely internal factors and external factors: Internal factors, the factors contained within the individual that affect procrastination. These factors include the physical condition eg, fatigue (tiredness); and the psychological condition of the individual (selfregulation), social anxiety, motivation, selfefficacy; External factors: the style of parenting and conducive environment. Nevertheless, these results differ when viewed in the analysis done partially. Where the partial results of the analysis showed differences in results between the two variables

\section{Self-concept and Procrastination}

In the self-concept discovered the positive influence self-concept of the students' academic procrastination. This means that increasing the self-concept of students has increased as well as 
their academic procrastination. What these results show the anomaly? because if the self-concept is defined as one's view of itself include assessment, thoughts, and attitudes against him (Burns, 1993), then it should procrastination (delays completion of academic assignments) should not have happened. But it appears that the self-assessment demonstrated high activity to procrastinate tasks too high. Commonly, procrastinators are trying to unravel why they do procrastination because they make a grace period execution of tasks called self -imposed deadlines. This implies that procrastinators usually wait for the information it deems necessary to make a good decision or complete a task. The kind of procrastination is positive if such information into consideration in making better decisions. So that the actual results of this study are not anomalies.

Based on these conditions, the procrastination can be divided into two types: procrastination dysfunctional that delays do not aim and hurt and procrastination functional namely delay and the reasons are strong, have a definite purpose so that it will not harm even be useful to be able to do constructive efforts so that a task can be finished well.

If you look at the subject matter of this study are students between the ages of 19-21 years are currently in the late adolescence phase. In theory at that age among other traits shown intelligence is the ability to think and act in a focused and process and effectively controlled environment (Sarlito, 2010). Besides, there is freedom of thought, raises one's courage in formulating hypotheses radical, freedom to explore the problem as a whole, and supports the courage of children to solve problems and draw new conclusions and correct. And emotionally, late teens are the culmination of the development of emotions, which is characterized by behavior that indicated influenced by the environment such as peers and activities undertaken in the daily environment, for example, participate in campus activities. Moreover, they are of childbearing age to indulge that semester IV and VI with the assumption that they will be active in addition to their expected college campuses are also participating in activities that expected to be supporting the student experience when becoming students

Though overall that case, the results of this study are not consistent with results of previous studies, such as the existence of a negative relationship between self-concept and procrastination (Triyono, 2012; Handayani and Suharnan, 2012; Research Usman\&Fitrianingsih (2020) which states that the relationship between self-concept procrastination looks from its appearance in a phase of human development, childhood early usually have had the cognitive ability is enough to understand that she separate from the environment and the people around him, this understanding is the embryo of a concept of self. The pattern of care that one of the parents of children. Their children can cause embarrassment and hesitation if allowed to continue will develop in adolescence and adulthood as a tendency for procrastination in various fields. Some researchers did find their common ground on several attitudes and behavior of people who do procrastination and those who have a negative self-concept (Al Momani, Al Rabadi, Freihat, 2020).

The self-concept becomes a personality style which is important for further study in research in this area because a person tends to act in line with the concept of self that he had, as a result of his actions also affect self-concept, early man. In the context of academic procrastination, procrastination tendencies task performed a learner can be seen from the beliefs, perceptions, or feelings of the student's own particular regarding himself in the academic realm. Research procrastination is always done let alone actual academic procrastination. Postponement of the tasks that should be completed on time with good results will have an impact on performance is low (Ferrari, et al 1995). It is influenced by several factors, such as personality factors such as selfefficacy and self-concept.

A negative self-concept is one of the factors that cause them to do academic procrastination. This is about the behavior of someone who tends to be in line with their perception of himself. Suitable with the results of studies on academic procrastination, delay behavior of construction or completion of 
tasks too often is counterproductive to results achieved, so that did not satisfactory to further maintain or reinforce negative perceptions of someone who is about competence in the academic field.

Procrastinator was often late to finishing the deadline has been determined, either by others or plans have been determined. Someone may have a plan to start a task at the appointed time, but when the time comes do not take action by what is planned, thus causing a delay or failure to finishing tasks adequately by doing other activities are more enjoyable than tasks should be done. Students who do procrastination deliberately do not do the job but spent the time to do other more enjoyable.

When referring to the Skinner's theory of operant conditioning that introduce their reward or punishment, it can be considered as a basic theory of procrastination given any academic work done by students if fun tends to be repeated and if it is not fun tend to be avoided or delayed to do it until you feel ready to rework. It can be stated that procrastination behavior arises as a result of the learning process, where a person who never felt succeed in doing when delays, likely to repeat his actions. Success delays ever felt would be considered a reward for repeat offenses postpone the future. The existence of other objects can give the gift of the object procrastinated can bring academic procrastination behavior. For example, participating in organizational activities may take more enjoyment in academic tasks.

Similarly, in terms of punishment, if the academic assignments effect punishment is not so strong, then the task is likely to be avoided, for example, students will face final exams are still long, then it certainly could be delayed preparation of learning rather than a weekly task that indeed the time is short. It happened because of the real risk that could be caused noticeably faster than the risk of delaying the study for semester examination.

\section{Self-efficacy and Procrastination}

The results of both studies were partially found in self-efficacy give effect negatively on procrastination. This means that the decline of self-efficacy will increase student academic procrastination. This is in line with the results of research conducted by Rahmawati (2011), Chaveza, Dennis Arias, et.all., (2020) which shows the negative effects of self-efficacy on student academic procrastination. Even Kristin, et.all., (2014) found that students who recorder high levels of procrastination assessed their goal achievement as being low. Meanwhile, students who recorded high self-efficacy had high achievement.

When referring to the social cognitive theory of Bandura, the social meaning of is that the thinking and activities of individuals starting from what was experienced in the community, or that the environment interact in a lesson that is meaningful to the individual. While cognitive interpreted as cognitive processes contributing to motivation, attitude and human behavior. So it can be stated that most of the knowledge and behavior of individuals are influenced by the environment and constantly undergoing a process of thinking on the information received. individual confidence born of mental processes and by stating that selfefficacy is conviction someone that he can carry out a certain task at all levels that affect the level of achievement of their duties. This theory view of learning as the acquisition of knowledge through cognitive processing of received, then procrastination to a given task will not happen.

Self-efficacy not something innate or genetic, but acquired, learned and developed from several sources of them experience success and achievement, that is, individuals who have experienced success (Bandura, 1986, 1994 in Rahman,U 2013), will be motivated to improve perseverance in overcoming adversity various jobs I reduce failure in this regard procrastination. Besides, the one aspect that encourages a person to avoid procrastination is their strength of conviction (strength) for his ability. Although the duty is not yet fully have the experience that supports, the hope strongly encourages the emergence of persistence in completing tasks given. Bisedes, the hope that weak capability makes himself easily swayed by thoughts that do not support. in other words, low self-efficacy 
marked by distress in the face of obstacles, their aspirations were low, in a difficult situation tends to think his weakness, and slow in restoring the feeling of being able after a failure (Bandura, 1997; 212). Likewise, the research results show a significant negative correlation between academic self-efficacy and problematic internet use (Odei, 2011). Then Zhang, Yanting, et.all., (2018) stated These findings suggest that interventions targeting the enhancement of self-efficacy for selfregulation and the conquest of fear of failure may prevent or reduce academic procrastination among undergraduates in health professions, especially for those with lower self-esteem.

In a study Bandura, the basic concept of selfefficacy theory derived from social cognitive theory. This theory view learning as the acquisition of knowledge through cognitive processes on the information received. The social aspect means that thought and human activity stems from what is learned in the community. The cognitive aspect means that there is a contribution of cognitive processes influence on motivation, attitudes, and behavior of humans. Thus the theory of self-efficacy involves the way people behave in certain situations that depend on reciprocal determinism, that is, a reciprocal relationship or causality between individual factors (such as cognition, affection, and events biology), environmental factors, and human behavior (Bandura 1977). In other words, how cognitive factors, behavior, and the environment associated with the belief that these individuals can or does not act satisfactorily.

Thus, students who have high self-efficacy will always try to perform various actions and ready to face difficulties. It is assumed for students in every lecture is charged tasks that require a lot of energy and often attention is quite serious, and often experience difficulties to complete the task, then the efficacy of students will determine how much effort expended and how he persevered in the face of obstacles and the painful experience in the tasks of college. The stronger the perceived self-efficacy of students, the more enterprising and industrious his efforts. When facing difficulties, students have great doubts about their ability to reduce their efforts or give up altogether.
While those who have a strong sense of efficacy using a greater effort to overcome the challenges and complete tasks to avoid procrastination. This study aims to gain further insights into the influence of self-concept and self-efficacy on student academic procrastination.

There are ten basic principles of self-efficacy to help procrastinators namely: 1 . Be calm and patient before writing; 2 . Before you feel ready to write, collect information, organize and create a framework of ideas; 3. Detailed tasks to daily activities; 4. Stop and do break when needed; 5. Balance the framework of the idea and the actual work; 6. Pay attention to negative thoughts and habits during the task; 7. Manage your emotions during work in a way to avoid the attitude of haste; 8. Avoid excessive emotions involved in the work; 9. Allow people to criticize the work and avoid dissipating energy as doing with fatigue; 10. Do some work that results can be observed in others (Anon).

\section{Conclusion}

Based on the results of data analysis and discussion, we can conclude several important things: There is the influence of self-concept and self-efficacy perpetually to students' academic procrastination of the Faculty of Education \& Teaching. This means that increasing self-concept and self-efficacy will decrease the level of student academic procrastination. The amount of the effective contribution of self-concept and selfefficacy on student academic procrastination by $30.1 \%$. It shows that there are other factors at $69.9 \%$, which can influence procrastination such as personality (introverts and extroverts), conformity. But the results obtained partially different, where there is a negative influence selfefficacy to academic procrastination. While there are positive influences on academic procrastination students of self-concept in the Faculty of Education \& Teaching.

\section{Acknowledgement}

Thank you to the Islamic State University of Alauddin Makassar for providing research funding so that this paper reaches the stage of publication 


\section{References}

[1] Arikunto, S. 2010. Prosedur Penelitian: Suatu Pendekatan Praktek. Reneka Cipta

[2] Bandura (1994) Self Efficacy. In, V.S. Ramachaudran (Ed), Encyclopedia of human behavior (Vol.4,pp.71-81).New York Academic Press.

[3] Bandura, A. (2005). Guide for constructing self-efficacy scales. In F. Pajares\& T. Urdan (Eds.), Self-efficacy beliefs of adolescents (307-337). Greenwich, CT: Information Age.

[4] Bandura, A. 1986. Social Foundations Of Thought And Action: A Social Cognitive Theory. New Jersey: Prentice-Hall, INC. Englewood Cliffs.

[5] Bandura, A., 1977. Social Learning Theory . New Jersey: Prentice-Hall, INC. Englewood Cliffs.

[6] Brown, W. F., \&Holtzman, W. H. (1953).Survey of Study Habits and Attitudes. Psychological Corp. J. Consult. Psychol., 1954, 18(2), 153-154), APAPsyc Net

[7] Burns, R.B, 1993. Konsep Diri. Terjemahan Edidari Self Concept, Liberty. Jakarta.

[8] Chaveza, Dennis Arias, et.al., (2020). "Self-Efficacy and Academic Procrastination: A Study Conducted in University Students of Metropolitan Lima", International Journal of Innovation, Creativity and Change, 11(10), 374.

[9] Chu and Choi. (2005). Rethinking Procrastination: Positive Effects of "Active" Procrastination Behavior on Attitudes and Performance. The Journal of Social Psychology, 145(3):245-64.

[10] Dyah Ayu Rahmawati (2011) Prokrastinasiakademikpenulisanskripsi, konsepdiriakademik, dandukungansosialteman, Tesis, UGM Yogyakarta

[11] FakriFalah AL-Momani, Wail Minwer AL-Rabadi, Aiman Mohammad Freihat, (2018). Self-Concept and Its Relationship with Academic Procrastination Among the Secondary Stage Students at Ajloun
Governorate "Evaluation Study". https://www.researchgate.net/publication/3 3357897

[12] Ferrari, J.R., Jhinson, J.L., danMcCown, W.G. 1995. Procrastination and Task Avoidance: Theory, Research, and Treatment. New Yor: Plenum Press

[13] Ghufron, M. Nurdan Rini Risnawita S Teori-TeoriPsikologi, Cet. III; Jogjakarta:

[14] Green, L. (1982). Minority students' selfcontrol of procrastination. Journal of Counseling Psychology, 29(6), 636644. APA PsycArticles. https://doi.org/10.1037/00220167.29.6.636

[15] Handayanidan Suharnan, 2012, Konsep Diri, Stres, dan Prokrastinasi Akademikpada Mahasiswa, Persona, Jurnal Psikologi Indonesia, September 2012, Vol. 1, No. 2, hal 114-121

[16] Hurlock.E.B. (2000). Psikologiper kembangan: suatupendekatansepanjangrentangkehidup an. Edisi Keenam. Jakarta: Airlangga

[17] Irshad, Hussain and Sarwat, Sultan (2010). Analysis of procrastination among university students Procedia - Social and Behavioral Sciences 5: 1897-1904. DOI: 10.1016/j.sbspro.2010.07.385

[18] Kandemira, Mehmet, (2014). "Reasons of Academic Procrastination: SelfRegulation, Academic Self-Efficacy, Life Satisfaction and Demographics Variables", Procedia-Social and Behavioral Sciences, 152(7), 188-193.

[19] Mera M, K., Sunny, H,L., Kevin,J, Nuter (2001) Academic procrastination prevention/intervention: Strategies and Recommendations. Journal of Developmental Education; Boone Vol. 25, Iss. 1, (Fall 2001): 14.

[20] Odaci, Hatice, (2011). "Academic SelfEfficacy and Academic Procrastination as Predictory of Problematic Internet Use in University Students", Computer and Education, 57(1), 1109-1113. DOI: 10.1016/j.compedu.2011.01.005

[21] Rahman, Ulfiani, (2013). Hubungan Antara Efikasidiridengan Burnout, Kepuasan Kerjadan Tingkah Laku 
Kewargaan Organisasi Dalam Kalangan Guru Sekolah Agama Sulawesi Selatan Indonesia. Disertasi. Universitas Kebangsaan Malaysia.

[22] Santoso, S (2011). Structural Equation Modelling (SEM). Jakarta: Kompas Gramedia

[23] Sarlito WirawanSarwono, (2010). Psikologi Remaja, Jakarta: Rajawali Press

[24] Soegiyanto, et.al., 2017. Behavior Patterns Of Academic Procrastination In Doing Final Projects. Cakrawala Pendidikan, Oktober 2017, Th. Xxxvi, No. 3

[25] Triyono, (2014). Hubungan Antara Efikasi Diri Dan Regulasi Emosi Dengan Prokrastinasi Akademik Siswa SMA. Tesis. Univ. Muhammadiyah Surakarta

[26] Usman, Osly, Firianingsih ,Hani., (2020). Effect of Self Concept, Self Efficacy and Self Esteem on Academic Procrastination, SSJR.

[27] Wascle, Kristin, et.al., (2014). "Procrastination and Self-Efficacy: Tracing Vicious and Virtuous Cireles in Slf-Regulated Learning", Learning and Instruction, $\quad 29$, 103-114.. https://doi.org/10.1016.learninsruc,2013,0 05 .

[28] Zhang, Yanting, et.all., (2018). SelfEfficacy for Self-Regulation and Fear of Failure as Mediators Between Self-Esteem and Academic Procrastination Among Undergraduates in Health Professions", Advances anHalth Sciences Education, 23, 817-830. DOI: 10.1007/s10459-018-98323 